application of kerosene and fi:h uil. Subsequently Mr. Maskell, dealing $\mathrm{u}$ ith the two species, says that a mixture of kerosene and linseed oil (one-third cr one-fourth of the former) as recommended by Mr. Comstock in America, had been perfectly successful so far as regards the Mytilas yis, which he does not regard as serious in its probable effect upon wattles (Acacia), bat very serious with respect to fruit and otber trees. On the other band, he considers all remedies useless against the Icerya of the wattle other than the radical one of cutting down and destroying the affected trees. No indication is given, however, of the use of a force-pump in distributing the kerosene; if this were used, the remedial agent might be distributed to a greater height than would be possible by mere hand application, and moreover it might be made to penetrate dense hedges, \&c., the interior of which it would be impossible to drench by hand labour. The improved form of application, as a "kerosene emulsion," recommended by Pruf. Riley and $\mathrm{Mr}$. Hubbard, did not appear to be known in New Zealand at the time the Report was drawn up. Any "ay it is satisfactory to hear that the judicious apulication of kerosene will certainly destroy scale insects without necessarily damaging the plants.

THE same Report speaks very hopefully of the ultimate success of attempts to cultivate hops in the province of Wellington; in Nelson success has been already secured. The great draw. back is the expense of pruviding the necessary poles, and much stress is laid upon the necessity for cultivating oak, ash, birch, and species of Eucalyptus for that purpose. Of the indigenous poles, those of Myrsine unvillei are said to be the most durable.

THE additions to the Zoological Society's Gardens during the past week include a Toque Monkey (Macacus pileatus $\$$ ) from Ceylon, presented by Mr. J. H. Barker; a Macaque Monkey (Macacus cynomolgus of) from India, presented by Mr. Douglas; a Common Marmoset (Hapale jacchus) from Brazil, presented by Mrs. Archer; a Moorhen (Gallinula chloropus), British, presented by Mr. T. E. Gunn; a Gannet (Sula bassana), British, presented by Mr. J. C. Baxter ; two St. Thomas's Conures (Conurus xantholemas) from St. Thomas, We-t Indies, presented by Mr. C. Wallis Enslie; two Fringed-lipped Lam. preys (Petromyzon branchialis), Briti-h, presented by the Rev. F. T. Wethered; a Pied Wagtail (Motailla lugubris), British; a Slaty Egret (Ardea gularis), European, furchased.

\section{INTERNATIONAL POLAR OBSERVATORIES}

I $B E G$ to inclose you an extract from a letter just received from Prof. Wild, President of the International Polar Committee, and which gives information as to the several expeditions which conducted observations in the circumpolar regions during the twelve months ending August 31, 1883.

\section{ROBERT H. SCOTT}

"I take this opportunity of stating concisely what I have hitherto learnt as to the present condition or the return of the various expeditions.

"I. The United States-Point Barrow.-The Expedition was to have returned in the summer of $188_{3}$. Definite information as to its return has not yet been received.

" 2. England and Canada-Fort Rae, on the Great Slave Lake.-According to a communication received from Mr. Scott, dated November 2I last, the Expedition has safely returned to England.

"3. United States-Lady Franklin Bay.-The attempts to relieve the Expedition this summer by ship have, like those of last year, failed owing to the unfavcurable condition of the ice. (Extract from newspapers.)

"4. Denmark-Godhavn, in Greenland.-According to a communication from Captain Hoffmeyer; dated December 8, the Expedition has safely returned to Copenhagen with a rich store of observations.

"5. Germany-Cumberland Sound (Davis Strait).-According to a communication received from Dr. Neumayer, dated

${ }^{\mathrm{I}}$ We believe this party arrived at San Francisco some weeks ago -ED.
November I, the Expedition has safely returned to Hamburg, having completed its task in a satisfactory manner.

"6. Count Wilczek's Station (Austria)-Jan Mayen, in Marymu:s Bay. - The Expedition has safely returned to Vienna, having completely carried out its programme. A short report of its operations has been published by $\mathbf{M}$. von Wohlgemuth, the Chief of the Expedition.

"7. Sw'eden-Spitzbergen (Cape Thordsen, in the Ice Fjord). -Dr. Rubenson states that the Expedition has safely returned to Stockbolm.

"8. Norway-Bossekop, near Alten.-From a letter from Prof. Mohn, dated September 7, the Expedition stopped work on August 31, having completely carried out its proyramme, and on September 17, according to a report in Na'uren (October, I883) it safely returned to Christiaria.

"9. Finland-Sodankyla. - The Expedition completed its task for the first year, but, according to a communication from Prof. Lenström, dated August 5, the otservations will be continued another year, as the Giovernment of Finland has provided the funds for the purpose.

" ro. Russia-Nova Zembla (Möller Bay).-The Expedition returned to St. Petersburg in October with a rich store of observations.

"11. Holland-The Kara Sea.-The Expedition could not reach its original place cf destination, Purt Dick: on, but was surrounded by ice in the Kara Sea, and has, according to a letter from Prof. Buys Ballot, dated October I, safely returned to Utrecht, having under the circumstances only imperfectly carried out its programme.

"I2. Russia-Mouth of the Lena (Sayastyr). - The Expedition, which suffered from storms during the passage doun the Lena, was not properly established tntil October 20,1882 ; from that date it has been able to carry out all the work laid down in the programme. It will continue its observations for another winter.

"I3. France-Cape Horn (Orange Bay, Terra del Fuego).According to a report from Prof. Mascart, dated November 17 , the Expedition has returned safely to Paris, with a rich store of materials.

"14. Germany-The Island of South Georgia (Moltke Harbour).- This Expedition has al:o safely returned, according to a communication from Dr. Neumayer.

"Of the fourteen Expeditions, therefore, three will continue their observations fur about another year (Lady Franklin Bay, Sodankyla, and Lena delta); the continuance of a fourth (Point Barrow) is at present unknown, the other ten have safely returned.'

\section{MOVEMENTS OF THE EARTH \\ III.-Rotation of the Earth}

THE several ideas concerning the movements of the earth which were introduced in the last lecture will in the present one have to be dealt with in greater detail.

It was then agreed that if the whole expanse of the heavens were to travel with a perfectly equable motion in one direction, such a motion for instance as would result from all the stars being fixed to a solid transparent substance like those crystal spheres that the ancients really be! ieved to exist; or if, on the other hand, the earth herself, instead of being free to turn as she listed with varying velocity in any direction, really went with perfect constancy in the direction oppo ite to the apparent motion of the stars, the visible effects would be the same in both cases, so that an appeal to our eyes would $n^{\prime}, t$ suffice to enable us to say whetber the earth moved or whether she remained at rest while the cele:tial sphere revolved around her.

Under these circumstances what is to be done? It has been seen bow, both with regard to the measurement of space and the measurement of time for astronomical purposes, those interested in the phy:ics and beauties of the various classes of celestial bodies outside our own earth have picked and chosen now one bit of physical science and now another to belp them in their inquiries; and with regard to this very important question, "Does the earth move or is she at rest?" we shall see how very beautifully and perfectly the question bas been answered by the application of certain mechanical principle:.

The majority of people, I suppose, have some acquaintance, however slight, with machinery-with steam engines for in-

\footnotetext{
${ }^{1}$ Continued from p. 69.
} 